RENATA TOMASZEWSKA-LIPIEC

Uniwersytet Kazimierza Wielkiego

$w$ Bydgoszczy

\title{
PRACA ZAWODOWA A FUNKCJONOWANIE RODZINY - ANALIZY I REFLEKSJE
}

\begin{abstract}
Tomaszewska-Lipiec Renata, Praca zawodowa a funkcjonowanie rodziny - analizy $i$ refleksje [Professional Work as a Threat to the Functioning of Family - Analysis and Reflections]. Studia Edukacyjne nr 43, 2017, Poznań 2017, pp. 165-176. Adam Mickiewicz University Press. ISSN 12336688. DOI: $10.14746 /$ se.2017.43.10

The article signals the problems of a complex influence that professional work, one of the key values, has over one's personal life. This issue seems to be the common area of scientific research for both pedagogy and sociology. Based on the EU27 as well as on Polish research results, a thesis has been formulated that professional work may nowadays be a threat to the functioning of the family.
\end{abstract}

Key words: family, work, society

„Życie ma podwójny wymiar. To życie składające się z dwóch części: pracy i rodziny, które tworza jedność. W rzeczywistości bowiem praca i rodzina są dwoma biegunami naszego życia indywidualnego, jak również społecznego. Każda z tych płaszczyzn jest odbiciem drugiej. Sq one nierozdzielne".

M.A. Barrere-Mauriso

\section{Wprowadzenie}

Od wielu lat w naukach społecznych ważnym przedmiotem analiz badawczych prowadzonych w różnych dyscyplinach jest praca człowieka. Stanowi ona podstawową formę aktywności jednostek, na której opiera się funkcjonowanie wszystkich społeczeństw na świecie. Pracę można również rozpatrywać jako wartość pozostającą $\mathrm{w}$ różnych relacjach $\mathrm{z}$ innymi warto- 
ściami tworzącymi system aksjonormatywny ludzi, w tym szczególnie z rodziną i zdrowiem. Celem niniejszego artykułu jest jednak zasygnalizowanie negatywnego wpływu pracy na życie rodzinne i osadzenie tego zagadnienia w kontekście konfliktu ról zawodowych i pozazawodowych, który można uznać za zagrożenie dla prawidłowego funkcjonowania jednostki w strukturach społecznych, takich jak rodzina i zakład pracy.

\section{"Rodzina - Zdrowie - Praca" - kluczowe wartości i „warunki szczęścia”}

W nawiązaniu do aksjologicznego wymiaru pracy należy wskazać, iż w świetle międzynarodowych porównawczych badań „European Values Study" w hierarchii wartości uznawanych za najważniejsze na pierwszym miejscu znajduje się rodzina. Praca zajmuje natomiast miejsce drugie. Dodać można, iż Polska jest w czołówce krajów, w których ponad 70\% badanych deklaruje uznanie pracy za wartość bardzo ważną (obok Turcji, Albanii, Bośni i Hercegowiny, Rumunii i Macedonii) ${ }^{1}$. Dane statystyczne uzyskiwane $z$ badań krajowych $^{2}$ wskazują z kolei, iż praca zajmuje kluczowe miejsce $\mathrm{w}$ systemach wartości rodaków, najczęściej w różnej konstelacji z rodziną (dziećmi i udanym małżeństwem) oraz zdrowiem.

Wyniki te nie są zaskakujące. Praca i rodzina to przecież główne obszary funkcjonowania ludzi dorosłych, którzy poświęcają tym sferom swój czas i energię. Dlatego, co należy podkreślić, ważne jest, aby jednostka była w stanie pogodzić obowiązki wynikające z ról społecznych przypisane obu tym obszarom życia.

Najwyższą w badaniach systemów wartości pozycję rodziny wyjaśniają analizy empiryczne prowadzone głównie w psychologii, zwłaszcza w psychologii pozytywnej. Wskazują, iż najsilniejszymi korelatami dobrostanu psychicznego (szczęścia) są udane relacje społeczne wynikające z silnej ludzkiej potrzeby przynależności, łączenia się i wiązania z innymi. Kiedy potrzeba ta zostaje zaspokojona przez przyjaźnie, związki intymne i małżeństwo, deklarowany w analizach statystycznych poziom szczęścia jest wysoki. Warto podkreślić, że ludzie pozostający w związku małżeńskim są prze-

${ }^{1}$ L. Halman, I. Sieben, M. van Zundert, Atlas of European Values: Trends and Traditions at the turn of the Century, Brill, Leiden the Netherlands 2011.

2 Zob. J. Czapiński, T. Panek (red.), Diagnoza Społeczna 2013. Warunki i jakość życia Polaków, Warszawa 2013; CBOS, Komunikat z badań BS 111/2013 Wartości i normy, Warszawa sierpień 2013. 
ciętnie szczęśliwsi i odznaczają się lepszym zdrowiem psychicznym oraz fizycznym w porównaniu z osobami, które nigdy nie wstąpiły $\mathrm{w}$ taki związek, pozostającymi w separacji i rozwiedzionymi. Dzieje się tak dlatego, ponieważ małżeństwo umożliwia spełnianie się $\mathrm{w}$ roli współmałżonka i rodzica (choć do pełnienia tej drugiej jest ono coraz mniej konieczne ze względu na rosnącą popularność alternatywnych form życia rodzinnego). Mimo że podjęcie zobowiązań małżeńskich i rodzicielskich może wywoływać u jednostki duży stres, to jednocześnie przynosi korzyści emocjonalne, m.in. w postaci wzmocnionego poczucia własnej tożsamości i wartości; zmniejszenia samotności; posiadania towarzysza/towarzyszki życia. Interesujące wydają się także, potwierdzone szerokimi badaniami naukowymi, zależności między posiadaniem dużej sieci związków społecznych, tj. dobrych relacji z rodziną, przyjaciółmi, współpracownikami w pracy, członkami kościoła lub innymi grupami a stanem zdrowia oraz minimalizowaniem ryzyka przedwczesnego zgonu. Przyczyn tego zjawiska jest wiele i mają one złożony charakter. $W$ tym miejscu zasygnalizować można, iż funkcjonowanie $\mathrm{w}$ środowisku, które zaspokaja naszą potrzebę przynależności sprzyja lepszej odporności systemu immunologicznego, obniżeniu hormonów stresu, możliwości zwierzenia się z bolesnych emocji. Trudniej natomiast ocenić badaczom znaczenie, jakie dla poczucia szczęścia ma praca zawodowa. Wydaje się oczywiste, że niechęć wzbudzać może myślenie o życiu obfitującym w ciężką pracę, a pozbawionym szczęścia. Z dotychczasowych badań naukowych wynika, iż jeśli pracy towarzyszą pozytywne emocje, to staje się ona zdecydowanie bardziej atrakcyjna. Ponadto, praca może stanowić źródło szczęścia, jeśli towarzyszący jej wysiłek nie jest wymuszony i rutynowy oraz nie trwa zbyt długo i nie uszczupla zasobów energii, jakimi dysponuje jednostka ${ }^{3}$.

Zasygnalizowane refleksje, będące rezultatem analiz empirycznych prowadzonych na całym świecie, znajdują swoje potwierdzenie również $\mathrm{w}$ odniesieniu do Polski (choć w naszym kraju kategoria przyjaźni pozostaje szczególnie niedoceniona). Nawiązując do warunków udanego i szczęśliwego życia wynikających z badań prowadzonych w ramach „Diagnozy Społecznej", można przytoczyć w następującej kolejności: zdrowie (64\% wskazań), udane małżeństwo (53\%), dzieci $(48 \%)$, pracę (31\%), pieniądze $(28 \%)$, opatrzność/Boga (13\%), uczciwość (10\%), przyjaciół (10\%), pogodę du-

${ }^{3}$ L.A. King, J.E. Eells, Ch.M. Burton, Pojęcie dobrego życia - w ujęciu waskim i szerokim [w:] Psychologia pozytywna w praktyce, red. P.A. Linley, S. Joseph, Warszawa 2007, s. 19-41; D.G. Myers, Związki z ludźmi a dobre życie: szukanie równowagi między interesem jednostki i wspólnoty w polityce spotecznej, [w:] Tamże, s. 389-412. 
cha/optymizm (10\%), życzliwość i szacunek otoczenia (7\%), wykształcenie $(6 \%)$, silny charakter (5\%), wolność/swobodę $(4 \%)^{4}$.

Jak wynika z powyższych danych, praca zajmuje czwarte miejsce $\mathrm{w}$ tej hierarchii, po zdrowiu, udanym małżeństwie i dzieciach. Odnosząc się zatem do tezy, iż rodzinę, zdrowie i pracę uznać można za kluczowe wartości, co jak się wydaje znajduje dostateczne potwierdzenie $\mathrm{w}$ źródłach naukowych, niepokojące wydają się dane statystyczne wskazujące, iż relacje zachodzące między tymi wartościami ulegają znaczącym przeobrażeniom. $\mathrm{Z}$ jednej strony przyjąć można, iż wskazane wartości są postulowane jako powszechnie cenione i uznawane składniki dobrej i sensownej egzystencji, z drugiej jednak obserwuje się nasilenie orientacji ludzi przede wszystkim na pracę zawodową. Szczególnie od przełomu XX i XXI wieku można zaobserwować, jak rozwija się społeczna tendencja do gloryfikowania etosu pracy jako dominującego czynnika rozwoju cywilizacyjnego. Ta swoista predylekcja i inklinacja pracy zawodowej nie pozostaje bez wpływu na przeżywanie i hierarchizację innych wartości tworzących systemy aksjonormatywne jednostek. Jak pisze na ten temat ks. Józef Tischner:

(...) praca stała się ostatnio terenem poddawanym podwójnemu przyciąganiu. Z jednej strony ukazuje się nam pracę jako coś najważniejszego w ludzkim życiu: praca czyni człowieka człowiekiem. (...) Z drugiej strony traktuje się pracę jako środek pomnażania własnego dobrobytu i dobrobytu najbliższych. Praca to po prostu źródło zarobku ${ }^{5}$.

Rozwijając przytoczony cytat, można wysunąć tezę, iż w coraz większym zakresie realizujemy się $\mathrm{w}$ pracy zawodowej kosztem jednak wartości rodzinnych, relacji społecznych, a także naszego zdrowia - czyli najsilniejszych korelatów dobrostanu psychicznego!

\section{W kierunku konfliktu praca - rodzina, czyli społeczeństwa "nierównowagi"}

Funkcjonowanie we współczesnej rzeczywistości społecznej, a zwłaszcza $\mathrm{w}$ dynamicznym środowisku pracy powoduje, że coraz więcej jednostek doświadcza "zakłóceń" w efektywnym wypełnianiu ról społecznych, a szczególnie roli rodzinnej i zawodowej. W literaturze naukowej problematykę tę określa się mianem dopasowania pracy i rodziny; równowagi praca-

${ }^{4}$ J. Czapiński, Ekonomia szczęścia i psychologia bogactwa, NAUKA, 2012, 1, s. 59.

${ }^{5}$ Ks. J. Tischner, Idąc przez puste błonia, Kraków 2005, s. 78 i n. 
rodzina, czy też szerzej równowagi praca-życie pozazawodowe. Przytoczone pojęcia wyrażają stopien, $\mathrm{w}$ jakim jednostka jest zaangażowana $\mathrm{w}$ obydwie te sfery życia i czas jaki im poświęca, a także satysfakcję jaką czerpie z obu rodzajów tych aktywności. Konflikt między wskazanymi obszarami może się objawiać dwojako: po pierwsze, praca może mieć negatywny wpływ na życie rodzinne; po drugie, to życie rodzinne może mieć negatywny wpływ na pracę ${ }^{6}$. Pierwszy ze wskazanych konfliktów stanowi przedmiot zainteresowań autorki i jest przez nią podejmowany w opracowaniach naukowych.

Zjawisko kumulacji ról we współczesnym świecie wykazuje tendencję wzrostową i dotyczy zarówno kobiet, jak i w coraz większym stopniu mężczyzn (co zostało zobrazowane w tabeli 1). Wydaje się, iż to wszechobecne przyspieszenie tempa życia, w połączeniu z rozwojem "nowej ekonomii” i związanej z nią utraty bezpieczeństwa zatrudnienia, przyczyniło się najsilniej do wyraźnego rozszerzania się sfery aktywności zawodowej kosztem innych obszarów życia osobistego, a szczególnie rodziny. W tym miejscu wspomnieć można, iż już w latach 70. XX wieku David Clutterbuck opisując ten konflikt, użył terminu „bigamia korporacyjna”, czyli „zaślubiny z firmą i współmałżonkiem". We wstępie swojej książki zatytułowanej Równowaga między życiem zawodowym a osobistym pisał wówczas, iż:

Wszystko zaczęło się od tortu weselnego. (...) Zobaczyłem go na okładce International Management, przedstawiającej pana młodego, który przerwał ceremonię, by odebrać telefon i podyktować sekretarce służbową notatkę. Panna młoda siedziała, płacząc nad tortem, a pastor bezradnie patrzył na to wszystko7.

Obecnie, jak wynika z „Trzeciego Europejskiego Badania Jakości Życia”8: -53,0\% respondentów z krajów UE27 deklaruje, iż przynajmniej kilka razy $\mathrm{w}$ tygodniu i kilka razy $\mathrm{w}$ miesiącu przychodzą z pracy do domu zbyt zmęczeni, aby wykonać podstawowe obowiązki domowe (w Polsce problemy takie zgłasza aż $61,3 \%$ badanych);

${ }^{6}$ Zob. H.J. Greenhaus, M.K. Collins, D.J. Shaw, The relation between work-family balance and quality of life, Journal of Vocational Behaviour, 2003, 63, s. 510-531; B. Moreno-Jimenez i in., Effects of Work-Family Conflict on Employee's Well-Being: The Moderating Role Of Recovery Experiences, IE Business School Working Paper C08-119-I 01-04-2008, źródło: http://lateen da.ie.edu/working_papers_economia/WP08-23.pdf [dostęp: 29.11.2015].

7 D. Clutterbuck, Równowaga między życiem zawodowym a osobistym, Kraków 2005, s. 11.

8 R. Anderson i in., Third European Quality of Life Survey Quality of life in Europe: Impacts of the crisis, Luxembourg 2012, s. 61-62.

Dane statystyczne dotyczące Polski pochodzą ze strony http://www.eurofound. europa.eu/surveys/data-visualisation/european-quality-of-life-survey-2012 [dostęp: 29.11. 2015]. 
- 30,0\% respondentów ma trudności z wypełnianiem obowiązków rodzinnych z powodu ilości czasu poświęcanego na aktywność zawodową (w Polsce jest to $45,3 \%$ wskazań);

- problemy ze skoncentrowaniem się na pracy z powodu zobowiązań wobec rodziny zgłasza natomiast $14 \%$ badanych (w Polsce wskaźnik ten jest większy i wynosi 26,3\%).

Szczegółowy materiał empiryczny na ten temat, z uwzględnieniem średniej liczby godzin przepracowanych w tygodniu i wieku respondentów w UE27, zawarto w tabeli 1.

Tabela 1

Wybrane wypowiedzi Europejczyków na temat konfliktu między pracą a życiem rodzinnym

\begin{tabular}{|c|c|c|c|c|c|c|}
\hline \multirow{2}{*}{$\begin{array}{c}\text { Średnia liczba } \\
\text { godzin przepra- } \\
\text { cowanych } \\
\text { w tygodniu }\end{array}$} & \multicolumn{2}{|c|}{$\begin{array}{c}\text { Zbyt zmęczony/a } \\
\text { by wykonywać prace } \\
\text { domowe } \\
(\%)\end{array}$} & $\begin{array}{c}\text { Trudność z wypełnia- } \\
\text { niem zobowiązań } \\
\text { rodzinnych } \\
(\%)\end{array}$ & \multicolumn{2}{|c|}{$\begin{array}{c}\text { Trudności } \\
\text { koncentrowaniu } \\
\text { się na pracy } \\
(\%)\end{array}$} \\
\cline { 2 - 7 } & mężczyźni & kobiety & mężczyźni & kobiety & mężczyźni & kobiety \\
\hline $\mathbf{2 1 - 3 4}$ & 38,0 & 52,0 & 15,0 & 24,0 & 9,0 & 13,0 \\
\hline $\mathbf{3 5 - 4 0}$ & 43,0 & 58,0 & 22,0 & 31,0 & 11,0 & 16,0 \\
\hline $\mathbf{4 1 - 4 7}$ & 56,0 & 71,0 & 32,0 & 37,0 & 13,0 & 16,0 \\
\hline $\mathbf{4 8 +}$ & 65,0 & 72,0 & 46,0 & 51,0 & 17,0 & 23,0 \\
\hline
\end{tabular}

Źródło: R. Anderson i in., Third European Quality of Life Survey Quality of life in Europe: Impacts of the crisis, Luxembourg 2012, s. 62.

Nawiązując do przytaczanego raportu, można dodać, iż:

- 48,5\% obywateli EU27, a 55,4\% Polaków nigdy nie angażuje się w opiekę nad dziećmi lub wnukami;

-75,5\% obywateli EU27, a 78,7\% Polaków nigdy nie angażuje się $\mathrm{w}$ opiekę nad osobami starszymi lub niepełnosprawnymi krewnymi;

- 10,1\% obywateli EU27, a 8,7\% Polaków nie utrzymuje bliskiego stosunku z matką i ojcem mieszkającymi poza gospodarstwem domowym;

- 32\% obywateli EU27, a 24\% Polaków pragnie spędzać więcej czasu z członkami swoich rodzin, a potrzebę choćby utrzymania stanu obecnego w tym zakresie deklaruje analogicznie $63,5 \%$ oraz $70,3 \%$ respondentów ${ }^{9}$.

9 Dane statystyczne pochodzą ze strony http://www.eurofound.europa.eu/surveys/ data-visualisation/european-quality-of-life-survey-2012 [dostęp: 29.11.2015]. Powyższe dane mogą wskazywać na zmianę stylu życia, ale również wynikać z zastosowanej przez autorów 
Na podstawie zasygnalizowanych badań EQLS można wysunąć tezę, iż łączenie sfery zawodowej i rodzinnej staje się coraz większym problemem społeczeństwa europejskiego. Nie dziwi zatem fakt, że coraz częściej w literaturze przedmiotu można spotkać się z następującymi określeniami oddającymi istotę społecznych przeobrażeń:

- „społeczeństwo galopujące" tzn. funkcjonujące w wirze pracy, w którym człowiek stał się niewolnikiem pieniądza - obiektu kultu kapitalizmu, i gdzie zmiany w sferze społecznej i kulturowej przekształcają się z laminarnych w turbulentne ${ }^{10}$;

- „społeczeństwo maniakalne” tzn. takie, w którym tempo pracy zwiększa się ponad dotychczasową miarę, a my stajemy się pokoleniem "ludzi z pasa do wyprzedzania", sprawdzających możliwości szybkiego życia i szybkich interesów ${ }^{11}$; to również społeczeństwo, w którym nasze życie na swoich skrzyżowaniach nie jest już regulowane czerwonym czy zielonym światłem, jest to raczej społeczeństwo „migającego, pulsującego żółtego światła"12;

- społeczeństwo „24 godzinne”13, w którym przestaliśmy uwzględniać uwarunkowania czasowe i rytmiczność przyrody, rozciągając naszą aktywność zawodową na każdą porę dnia i nocy. Tym samym, stworzyliśmy zagrożenie dla naszego zdrowia fizycznego i psychicznego, jak również życia małżeńskiego oraz rodzinnego.

$\mathrm{W}$ związku z narastającymi trudnościami w analizowanej materii, łączenie obu wskazanych sfer stało się ważnym zagadnieniem postulowanym w obszarze europejskiej polityki społecznej; znalazło również odzwierciedlenie w Karcie Praw Podstawowych Unii Europejskiej zawierającej zestawienie najważniejszych praw, wolności i zasad skierowanych do obywateli państw członkowskich.

Ranga, jaką nadaje się temu zagadnieniu wynika przede wszystkim z negatywnych implikacji pojawiających się lawinowo na skutek postępującej ingerencji pracy zawodowej szczególnie w obszar życia rodzinnego.

raportu metodologii. Szczególne zdziwienie mogą budzić informacje dotyczące aktywności Polaków, którzy w obiegowej opinii postrzegani są jako osoby bardzo „rodzinne”.

${ }^{10}$ W. Sztumski, Turboświat, pułapka przyspieszenia i ekologia czasu, [w:] Czas w życiu człowie-

ka, red. K. Popiołek, A. Chudzicka-Czupała, Katowice 2010, s. 25-35.

${ }^{11}$ R. Holden, Inteligencja sukcesu, Warszawa 2004, s. 28.

12 Zob. J.B. Fabry, Introduzione alla logoterapia, Roma 1970.

${ }_{13}$ Zob. L. Kreitzman, The 24 Hour Society, Profile Books 1999. 


\section{Wpływ pracy zawodowej na sferę życia rodzinnego - wybrane przykłady}

Wpływ pracy zawodowej na życie rodzinne jest złożony. Praca stanowi podstawowe źródło dla wypełniania materialno-ekonomicznej funkcji rodziny; jest również silnie powiązana z jej funkcją prokreacyjną, opiekuńczą, socjalizacyjną i socjopsychologiczną. W nawiązaniu do refleksji zaprezentowanej w pierwszej części artykułu, w której wartość rodziny identyfikowana była ze szczęśliwym małżeństwem i posiadaniem dzieci, w tej części zasygnalizować można takie skutki tego wpływu, jak np.:

\section{Spadek częstości zawierania matżeństw}

Odkładanie ślubu „na później” bądź całkowite odrzucenie możliwości sformalizowania związku stanowią rozwiązania coraz częściej praktykowane również w Polsce. Według CBOS, 63\% badanych respondentów akceptuje fakt, że ludzie, tymczasowo lub definitywnie, rezygnują z małżeństwa. Przyczyn spadku gotowości do jego zawierania, oprócz preferowania życia bez zobowiązań, upatruje się $\mathrm{w}$ obawie przed nieudanym związkiem, trudnościach $\mathrm{w}$ znalezieniu odpowiedniego kandydata/kandydatki, czy lęku przed problemami finansowymi i mieszkaniowymi, właśnie $\mathrm{w}$ strachu przed obowiązkami rodzicielskimi (wskazania 11\% kobiet i $24 \%$ mężczyzn), a także $\mathrm{w}$ postrzeganiu założenia rodziny jako przeszkody $\mathrm{w}$ realizacji kariery zawodowej (wskazania 34\% kobiet i 19\% mężczyzn) ${ }^{14}$.

\section{Zmniejszenie się skłonności do posiadania dzieci}

Liczba dzieci $\mathrm{w}$ rodzinie stanowi jeden $\mathrm{z}$ istotnych parametrów konfliktu ról. W 2013 roku liczba urodzeń w Polsce spadła poniżej 370 tys. - spadek o 4,3\%. Na 27 krajów Unii Europejskiej zajmujemy 25. miejsce pod względem współczynnika dzietności. Obecnie Polska ma jeden z najniższych w Europie współczynników urodzeń - 1,315. Powodów rezygnacji z potomstwa jest wiele. Znamienne może być zidentyfikowane zarówno nieposiadanie zatrudnienia, jak i jego posiadanie. $Z$ danych "Diagnozy społecznej” wynika, iż do przyczyn tych należą: trudna sytuacja materialna, brak pracy i niepewność zatrudnienia (85\% Polaków uznało ten czynnik za ważny lub bardzo ważny); niemożność zajścia w ciążę (85\%); złe warunki mieszkanio-

${ }^{14}$ CBOS, Komunikat z badań nr BS/32/2013 Społeczne oceny alternatyw życia matżeńskiego, Warszawa marzec 2013.

${ }^{15}$ Lewiatan, Czas na kobiety. Superwoman na rynku pracy, Warszawa 2014, s. 49. 
we (74\%); brak odpowiedniego partnera (69\%); ryzyko chorób genetycznych dziecka (69\%); niepewność przyszłości (67\%); trudności w godzeniu pracy i rodzicielstwa (63\%); wysokie koszty wychowania dzieci $(62 \%)$; brak miejsc lub zbyt wysokie opłaty w żłobkach i przedszkolach (61\%); zbyt niskie zasiłki na urlopach macierzyńskich i wychowawczych $(60 \%)^{16}$. W nawiązaniu do wymienionych czynników wydaje się, iż za istotne uznać można odpowiedzi $63 \%$ badanych wskazujące na problemy godzenia pracy zawodowej i rodzicielstwa jako ważnego lub bardzo ważnego powodu, dla którego ludzie w Polsce nie decydują się na posiadanie dzieci.

\section{Odktadanie decyzji o urodzeniu dziecka}

Z badań Diagnozy Społecznej, a także z badania ankietowego Generations and Gender Survey (GGS-PL) wynika, iż kobiety i mężczyźni w Polsce generalnie chcą i zamierzają mieć dzieci. Skala planowanej bezdzietności jest niewielka i zbliżona u przedstawicieli obu płci (13\% mężczyzn i 10\% kobiet nie planuje posiadania potomstwa). Wyraźne przesunięcie wieku, w którym planuje się rodzicielstwo powoduje, iż kobiety pragną zostać matkami nawet po ukończeniu 35. roku życia, co należy szczególnie wyartykułować:

- z jednej strony aktywność zawodowa sprzyja planowaniu pierwszego dziecka - zarówno u kobiet, jak i u mężczyzn podjęcie takiej decyzji w perspektywie krótkoterminowej, tj. trzech lat, umożliwia osiągnięta stabilizacja materialna, a pod pojęciem której rozumie się posiadanie mieszkania oraz pracy przez obojga partnerów;

- z drugiej strony aktywność zawodowa nie sprzyja planowaniu dalszego potomstwa właśnie ze względu na konflikt między posiadaniem pracy a opieką nad dzieckiem ${ }^{17}$.

\section{Wzrost aspiracji zawodowych kobiet}

Choć w Polsce kobiety stanowią na razie około $45 \%$ ogółu pracujących, to obserwuje się stały wzrost ich aktywności zawodowej. Według badań CBOS, w ocenie wpływu pracy zawodowej kobiet na jakość ich życia rodzinnego najczęściej dominuje pogląd, że korzyści przeważają nad stratami

${ }^{16}$ M. Styrc, Bariery rodzicielstwa w percepcji Polaków, [w:] Niska dzietność w Polsce w kontekście percepcji Polaków. Diagnoza Społeczna - raport tematyczny, red. I.E. Kotowska, Warszawa 2014, s. 61.

${ }_{17}$ M. Młynarska, Zamierzenia prokreacyjne Polaków i ich zróżnicowanie wedtug cech demograficznych i ekonomicznych respondentów [w:] Niska dzietność w Polsce, s. 52-61; I.E. Kotowska, Jaka polityka wspierająca decyzje rodzicielskie jest w Polsce potrzebna, [w:] Tamże, s. 99-104. 
(39\% odpowiedzi $)^{18}$. Okazuje się także, iż dla samorozwoju kobiet nie jest najważniejsza rodzina, lecz praca, świadomość bycia potrzebną i realizacja własnych uzdolnień. Sukcesem nie jest $\mathrm{w}$ oczach kobiet założenie rodziny, lecz właśnie znalezienie satysfakcjonującej pracy zawodowej. Dlatego większość z nich nie zakłada długiego pozostawania z dzieckiem po porodzie, a chce możliwie najszybciej wrócić do aktywności w tej sferze ${ }^{19}$.

5. Obciążenie wielościa zadań oraz postrzeganie pracy i rodziny jako wzajemnie konkurencyjnych

Wzrostowi aktywności zawodowej kobiet towarzyszy zbyt powolny jeszcze proces kształtowania się nowego partnerskiego modelu, w którym oboje rodzice dzielą między sobą obowiązki i odpowiedzialność za wychowanie dzieci oraz za sytuację finansową rodziny. $Z$ badań wynika, iż kobiety w pracy spędzają średnio 39 godzin, tylko 2 godziny mniej od mężczyzn, zaś na nieodpłatne prace domowe przeznaczają 31 godzin $w$ tygodniu, podczas gdy mężczyźni zalewie 9 godzin. Ponad 6,5 razy więcej kobiet $(1,3 \mathrm{mln})$ nie zmienia swojego statusu na rynku pracy z powodu obowiązków rodzinnych i związanych z prowadzeniem domu. Według Eurostatu, nieaktywne zawodowo kobiety są nieaktywne przede wszystkim z przyczyn rodzinnych lub osobistych (50\%). Na drugim miejscu jest choroba / niepełnosprawność, trzeci zaś powód wynika z dalszego kształcenia się ${ }^{20}$. Co istotne, w Polsce, jak wskazują dane przytaczanej już „Diagnozy Społecznej”, co druga kobieta w wieku 25-44 lata również wskazuje opiekę nad dzieckiem jako główny powód swojej nieaktywności zawodowej.

\section{Zmiany w ilości czasu spędzanego wspólnie}

Odnosząc się do dyspozycji czasowej polskich rodziców, można wskazać, iż najczęściej chodzą oni ze swoimi dziećmi na zakupy lub z wizytą do rodziny czy znajomych. Rzadziej - w porównaniu z zapytanymi 10 lat temu - mają czas, by codziennie z dzieckiem: zjeść posiłek (spadek o 30 punktów procentowych) porozmawiać na różne tematy (spadek o 14 punktów procentowych), a nawet usiąść i spędzić czas przed telewizorem (spadek o 14 punktów procentowych). Stosunkowo najgorzej wygląda kwestia wspólnego odrabiania lekcji - codziennie robi to mniej niż jedna trzecia ankietowanych. Ponadto, w prawie połowie rodzin wspólny posiłek przestał należeć już do

18 CBOS, Komunikat z badań nr BS/28/2013 Kobieta pracująca, Warszawa marzec 2013.

19 A. Orzeszek, Miejsce rodziny i pracy w planach życiowych kobiet. Studium empiryczne, [w:] Rodzina polska. Wybrane aspekty funkcjonowania, red. M. Szyszka, Lublin 2013, s. 31-45.

${ }^{20}$ Lewiatan, Czas na kobiety, s. 44, 51. 
codzienności, podczas gdy w 2004 roku był on raczej czymś powszechnym (wówczas było to aż $83 \%$ wskazań) ${ }^{21}$.

Zaprezentowane wybrane przykłady wpływu pracy na procesy rozwoju i funkcjonowania rodziny uzasadniają tytuł niniejszego artykułu. Wynika $\mathrm{z}$ nich, iż praca zawodowa może, a w wielu przypadkach stanowi zagrożenie dla funkcjonowania tej podstawowej komórki społecznej.

\section{Podsumowanie}

Konkludując przedstawioną refleksję, można napisać, iż praca zawodowa stanowi ważny obszar ludzkiej aktywności, dzięki któremu zaspokajamy potrzeby egzystencjalne i psychospołeczne. Nie może ona jednak dezorganizować innych sfer naszego życia. Wręcz przeciwnie, powinna tworzyć warunki dla wielowymiarowego samorealizowania się jednostki właśnie w obszarze życia rodzinnego. Dlatego, współcześnie zwraca się coraz większą uwagę na charakter relacji zachodzących między pracą zawodową a życiem pozazawodowym. Analizowanie związków między tymi obiema sferami wymaga uwzględniania ich dwukierunkowego charakteru. Każda z nich może być źródłem zarówno pozytywnych, jak i negatywnych wpływów w odniesieniu do różnych aspektów funkcjonowania w nich jednostki. $\mathrm{Z}$ jednej strony badacze wskazują na wzajemnie pozytywne wpływy obu tych obszarów, dzięki którym następuje ubogacanie i wzmacnianie pełnionych w ich ramach ról społecznych. Z drugiej zaś strony, wskazują na postępującą dezintegrację $\mathrm{w}$ relacjach zachodzących pomiędzy sferą zawodową i pozazawodową, w tym zwłaszcza rodzinną, a przejawiającą się dominacją tej pierwszej. Dezintegracja ta może być analizowana w kategoriach zagrożeń tak indywidualnych, jak i społecznych. Złożoność i wieloaspektowość podjętego zagadnienia generują potrzebę, aby wzajemne relacje między tymi tak ważnymi sferami życia człowieka stanowiły znaczący obszar badań naukowych, zwłaszcza nauk społecznych.

\section{BIBLIOGRAFIA}

Anderson R., Dubois H., Leončikas T., Sándo E., Third European Quality of Life Survey Quality of life in Europe: Impacts of the crisis, Publications Office of the European Union, Luxembourg 2012.

CBOS, Komunikat z badań nr BS/28/2013 Kobieta pracująca, Fundacja Centrum Badania Opinii Społecznej, Warszawa marzec 2013.

${ }^{21}$ TNS, Ile czasu rodzice poświęcają swoim dzieciom? Warszawa lipiec 2014. 
CBOS, Komunikat z badań nr BS/32/2013 Społeczne oceny alternatywy życia małżeńskiego, Fundacja Centrum Badania Opinii Społecznej, Warszawa marzec 2013.

CBOS, Komunikat z badań BS 111/2013 Wartości i normy, Fundacja Centrum Badania Opinii Społecznej, Warszawa sierpień 2013.

Clutterbuck D., Równowaga między życiem zawodowym a osobistym, Oficyna Ekonomiczna, Kraków 2005.

Czapiński J., Ekonomia szczęścia i psychologia bogactwa, NAUKA, 2012, 1.

Czapiński J., Panek T. (red.), Diagnoza Społeczna 2013. Warunki i jakość życia Polaków, Rada Monitoringu Społecznego, Warszawa 2013.

Greenhaus H.J., Collins M.K., Shaw D.J., The relation between work-family balance and quality of life Journal of Vocational Behaviour, 2003, 63.

Halman L., Sieben I., van Zundert M., Atlas of European Values: Trends and Traditions at the turn of the Century, Brill, Leiden, the Netherlands, 2011.

Holden R., Inteligencja sukcesu, Amber, Warszawa 2004.

Eurofound, http:/ /www.eurofound.europa.eu/surveys/data-visualisation/european-qu ality-of-life-survey-2012 [dostęp: 29.11.2015].

King L.A., Eells J.E., Burton Ch.M., Pojęcie dobrego życia - w ujęciu waskim i szerokim, [w:] Psychologia pozytywna w praktyce, red. P.A. Linley, S. Joseph, PWN, Warszawa 2007.

Kotowska I.E., Jaka polityka wspierajaca decyzje rodzicielskie jest w Polsce potrzebna, [w:] Niska dzietność w Polsce w kontekście percepcji Polaków. Diagnoza Społeczna - raport tematyczny, red. I.E. Kotowska, Ministerstwo Pracy i Polityki Społecznej, Warszawa 2014.

Lewiatan, Czas na kobiety. Superwoman na rynku pracy, Konfederacja Lewiatan, Warszawa 2014.

Młynarska M., Zamierzenia prokreacyjne Polaków i ich zróżnicowanie wedtug cech demograficznych i ekonomicznych respondentów, [w:] Niska dzietność w Polsce w kontekście percepcji Polaków. Diagnoza Społeczna - raport tematyczny, red. I.E. Kotowska, Ministerstwo Pracy i Polityki Społecznej, Warszawa 2014.

Moreno-Jimenez B., Mayo M., Sanz-Vergel A.I., Geurts S., Rodrlguez-Muńoz A., Garros E., Effects of Work - Family Conflict on Employee's Well-Being: The Moderating Role of Recovery Experiences, IE Business School Working Paper C08-119-I 01-04-2008, źródło: http://latienda.ie.edu/working_papers_economia/WP08-23.pdf [dostęp: 29.11. 2015].

Myers D.G., Związi z ludźmi a dobre życie: szukanie równowagi między interesem jednostki i wspólnoty w polityce społecznej, [w:] Psychologia pozytywna w praktyce, red. P.A. Linley, S. Joseph, PWN, Warszawa 2007.

Orzeszek A., Miejsce rodziny i pracy w planach życiowych kobiet. Studium empiryczne, [w:] Rodzina polska. Wybrane aspekty funkcjonowania, red. M. Szyszka, Elpil, Lublin 2013.

Styrc M., Bariery rodzicielstwa w percepcji Polaków, [w:] Niska dzietność w Polsce w kontekście percepcji Polaków. Diagnoza Społeczna - raport tematyczny, red. I.E. Kotowska, Ministerstwo Pracy i Polityki Społecznej, Warszawa 2014.

Sztumski W., Turboświat, pułapka przyspieszenia i ekologia czasu, [w:] Czas w życiu człowieka, red. K. Popiołek, A. Chudzicka-Czupała, Wydawnictwo Uniwersytetu Śląskiego, Katowice 2010.

Tischner J. ks., Idąc przez puste błonia, Społeczny Instytut Wydawniczy „Znak”, Kraków 2005.

TNS, Ile czasu rodzice poświęcają swoim dzieciom?, Warszawa lipiec 2014. 